\title{
Effect of Different Chemicals on Seedling Growth and Biomass of Chironji (Buchanania lanzan Spreng.)
}

\author{
C.J. Joshi ${ }^{1 *}$, D.K. Sharma ${ }^{2}$, Mutteppa Gotur ${ }^{1}$ and Rajni Rajan ${ }^{1}$ \\ ${ }^{1}$ Department of Fruit Science, ASPEE College of Horticulture and Forestry, \\ Navsari, Gujarat, India \\ ${ }^{2}$ Agriculture Experimental Station Paria, NAU, Navsari Agricultural University, Navsari, \\ Gujarat-396450, India \\ *Corresponding author
}

\begin{tabular}{|c|c|}
\hline & A B S T R A C T \\
\hline $\begin{array}{l}\text { Chironji, Charoli, } \\
\text { Buchanania lanzan } \\
\text { Spreng, Seedling } \\
\text { growth, GA3, } \\
\text { KNO3, Scarification, } \\
\text { Biomass. }\end{array}$ & \multirow{3}{*}{$\begin{array}{l}\text { The seeds of Chironji (Buchanania lanzan Spreng.) were treated with } \mathrm{H}_{2} \mathrm{SO}_{4}(5 \text { percent), } \\
\text { Mechanical scarification, } \mathrm{GA}_{3}(200 \text { and } 300 \mathrm{ppm}), \mathrm{KNO}_{3}(1 \mathrm{and} 2 \text { per cent), Thiourea (1) } \\
\text { per cent), Biomix }(50 \mathrm{~g} \text { per kg seed), Cow urine }(5 \text { per cent) Cow dung slurry }(5 \text { per cent) } \\
\text { and soaking in distilled water as control for } 24 \text { hours. The maximum seedling height }(6.35 \text {, } \\
15.21 \text {, and } 36.78 \mathrm{~cm}) \text {, seedling diameter }(0.21,0.35 \text { and } 0.45 \mathrm{~cm}) \text { and number of leaves per } \\
\text { plant }\left(4.90,10.22 \text {, and } 14.63 \mathrm{~cm} \text { ) was found in seeds treated with } \mathrm{GA}_{3} 200 \mathrm{ppm} \text { treatment }\right. \\
\text { at } 60,120 \text { and } 180 \mathrm{DAS} \text { respectively. Similarly, maximum leaf area }\left(48.47 \mathrm{~cm}^{2}\right) \text { was also } \\
\text { found in seeds treated with } \mathrm{GA}_{3} 200 \mathrm{ppm} \text { treatment at } 180 \mathrm{DAS} \text {. Maximum fresh weight } \\
\text { of shoot and root }(14.33 \mathrm{~g} \text { and } 8.22 \mathrm{~g} \text { respectively), dry weight of shoot and root }(8.10 \mathrm{~g} \\
\text { and } 4.25 \mathrm{~g} \text { respectively) and total biomass }(12.83 \mathrm{~g}) \text { was also noticed in seeds subjected to } \\
\mathrm{GA}_{3} 200 \mathrm{ppm} \text { treatment at the end of the experiment (180 DAS). Pre sowing treatment like } \\
\mathrm{GA}_{3} 200 \mathrm{ppm} \text { and mechanical scarification found equally better on growth and biomass } \\
\text { parameters of Chironji seedlings. }\end{array}$} \\
\hline Article Info & \\
\hline $\begin{array}{l}\text { Accepted: } \\
\text { 21 July } 2017 \\
\text { Available Online: } \\
\text { 10 September } 2017\end{array}$ & \\
\hline
\end{tabular}

Introduction

Chironji or Charoli, (Buchanania lanzan Spreng.), a member of the family Anacardiaceae, originated in the Indian subcontinent, is an excellent tree of agro forestry. It assumes great significance due to its multifarious uses and capacity to withstand adverse climatic conditions. At present, it is growing under forest condition as an under exploited fruit and gives monitory reward to tribal community of the country. The oily kernels are the most important part and are used in preparation of puddings. The kernel is highly nutritious and rich in protein (25-30\%) and yield sweet oil, which can be used to substitute olive and almond oil. It is a medium size tree, up to $40-50 \mathrm{ft}$. height with a straight trunk. Trees have the alternate bearing nature as present in the mango. It flowers in the month of January- February and ripen in April-May.

Kernels are of very high value and fetch Rs. $800-1000$ per $\mathrm{kg}$ in market. The tree is found growing as wild in the tropical deciduous forests of north, west and central India mostly in the states of Madhya Pradesh, Bihar, Orissa, Andhra Pradesh, Chhattisgarh, Jharkhand, Gujarat, Rajasthan and 
Maharashtra. In Gujarat, it is found mainly in Dang, Valsad, Vadodara and Dahod district. Buchanania lanzan being a vulnerable medicinal plant is included in the Red Data Book published by International Union for Conservation of Nature and Natural Resources (IUCN).

This species has high socioeconomic value providing livelihood to tribal population of the area and has high potential as commercial horticulture species. Unfortunately, overexploitation and indiscriminate harvesting (lopping and cutting) leading severe threat to it, hence urgent conservation efforts are required at all levels. Chironji seeds exhibits poor germination percentage even if exposed to favourable conditions of germination owing to seed dormancy. It may be due to morphological factors such as hard seed, thick testa or due to incorrect storage or handling (secondary dormancy). Such condition ultimately leads to reduced vegetative growth and biomass of chironji seedlings.

Thus, such seeds may require special treatments like stratification, scarification, soaking in water, growth regulators etc., for overcoming dormancy with better vegetative growth. Pre-sowing treatment with chemicals like $\mathrm{GA}_{3}, \mathrm{KNO}_{3}$ and thiourea (Rajamanickam et al., 2002) improve the seed germination and vegetative growth of chironji.

It is felt that chironji plantation can be conserved and increased by bringing more area under new plantations. Keeping these facts in mind and also to meet out the local demand of quality planting material of chironji, the research work on effect of different chemicals on seedling growth and biomass of chironji (Buchanania lanzan Spreng.) was conducted for developing a suitable technology facilitating easy multiplication, regeneration and conservation of this important species.

\section{Materials and Methods}

The present investigation was carries out at Agriculture Experimental Station, Navsari Agricultural University, Paria, Valsad (Gujarat), India during 2016-2017. The experimental design was Completely Randomized Design (CRD). Eleven different treatments were imposed including control. Fresh seeds from fruits were collected from the forest area of Rajpipla region (Narmada, Gujarat). Healthy seeds of uniform size were selected and used for the experiment. Hundred seeds were used for each treatment, which was replicated thrice. The treatments were $\mathrm{T}_{1}-\mathrm{H}_{2} \mathrm{SO}_{4}$ at $5 \% \quad(10 \mathrm{~min}),. \mathrm{T}_{2^{-}}$ Mechanical scarification (Breaking hard seed coat by hammering), $\mathrm{T}_{3}-\mathrm{GA}_{3}$ at $200 \mathrm{ppm}$ (24 $\mathrm{hr}), \mathrm{T}_{4}-\mathrm{GA}_{3}$ at $300 \mathrm{ppm}(24 \mathrm{hr}), \mathrm{T}_{5}-\mathrm{KNO}_{3}$ at $1 \%(24 \mathrm{hr}), \mathrm{T}_{6}-\mathrm{KNO}_{3}$ at $2 \%(24 \mathrm{hr}), \mathrm{T}_{7-}$ Thiourea at $1 \%(24 \mathrm{hr}), \mathrm{T}_{8}$-Biomix at $50 \mathrm{gm} / \mathrm{kg}$ seed $(24 \mathrm{hr}), \mathrm{T}_{9}$-Cow urine at $5 \%$ (24 hr), $\mathrm{T}_{10^{-}}$Cow dung at 5\% (24 hr), $\mathrm{T}_{11^{-}}$ Control (Water soaking for $24 \mathrm{hr}$ ). Before sowing all seeds were soaked in water for 24 hours and after that seeds were dipped in chemicals for 24 hour except seeds treated with concentrated $\mathrm{H}_{2} \mathrm{SO}_{4}$ which were dipped for 10 minutes. Hard seed coats were broken down by hammering in seeds which are treated with mechanical scarification before sowing. Biomix solution is made up by mixing equal amount of Phosphate solubilising bacteria, Azospirillum, Trichoderma viridae and Pseudomonas fluroscence. After imposing treatments, the seeds were shade dried for 10 minutes and were sown in polythene bag containing media 1:1:1 ratio (Soil, FYM, Sand) at $1 \mathrm{~cm}$ depth and were kept in the poly house. The polythene bags were watered daily till final data were recorded. Observations were recorded monthly for vegetative parameters and 180 DAS for biomass parameters since the date of seed sowing. Fresh weight of shoot and root was taken on electronic balance. The 
fresh weighed seedlings were used and they were placed in brown paper bags, properly labeled and dried in oven at $60^{\circ} \mathrm{C}$ and after stabilization of weight, this stabilized weight was recorded as a dry weight of shoot and root. The data collected from the five labelled seedlings in each treatment in a repetition were averaged and subjected to statistical analysis (Panse and Sukhatme).

\section{Results and Discussion}

\section{Vegetative growth characters}

Height, diameter, number of leaves and leaf area are the important parameters in judging quality of seedlings. All the treatments seem to play positive role (Table 1) in improving the vegetative growth characters of chironji under the present study. The maximum seedling height $(6.35,15.21$, and $36.78 \mathrm{~cm})$, seedling diameter $(0.21,0.35$ and $0.45 \mathrm{~cm})$ and number of leaves per plant $(4.90,10.22$, and $14.63 \mathrm{~cm}$ ) was found in seeds treated with $\mathrm{T}_{3}\left(\mathrm{GA}_{3}\right.$ at $\left.200 \mathrm{ppm}\right)$ treatment at 60,120 and 180 DAS respectively which was at par with $\mathrm{T}_{2}$ (mechanical scarification) treatment recording seedling height $(6.20,14.32$ and $35.26 \mathrm{~cm})$, seedling diameter $(0.19,0.33$ and $0.43 \mathrm{~cm})$ and number of leaves per plant $(4.67, \quad 9.77$ and $13.61 \mathrm{~cm})$.Similarly, maximum leaf area $\left(48.47 \mathrm{~cm}^{2}\right)$ was also recorded in treatment $\mathrm{T}_{3}\left(\mathrm{GA}_{3}\right.$ at $\left.200 \mathrm{ppm}\right)$ followed by $\mathrm{T}_{2}$ (mechanical scarification) treatment recording leaf area $\left(48.37 \mathrm{~cm}^{2}\right)$ at 180 days after sowing. Minimum seedling height $(6.20,14.32$ and $35.26 \mathrm{~cm})$, stem diameter $(0.11,0.17$ and $0.24 \mathrm{~cm})$, leaves per plant $(2.21,4.99$ and $8.70 \mathrm{~cm})$ and leaf area $\left(18.12 \mathrm{~cm}^{2}\right)$ was noticed in control.

The increased seedling height with $\mathrm{GA}_{3}$ treatment might be due to the fact that this hormone increased osmotic uptake of nutrients, causing cell elongation and thus increasing height of the plant and stem diameter was also increased due to greater cell division and elongation at the stem portion (Sen et al., 1990). The production of more number of leaves might be due to higher growth of seedlings and also due to activity of $\mathrm{GA}_{3}$ at the apical meristem resulting in more synthesis of nucleoprotein responsible for increasing leaf initiation (Sen and Ghunti, 1976).

The maximum leaf area might be due to increase in leaf length and width, which ultimately increased in leaf area of the plant. Present findings are supported by (Sharma 2016) in chironji who revealed that the considerable plant height $(31.33 \mathrm{~cm})$ and number of leaves (13) was recorded by seed treatment with $\mathrm{GA}_{3}$ at 200 ppm concentration. Similarly, Muralidhara et al., (2015) also found better plant height $(21.6 \mathrm{~cm})$, more number of leaves (22.5) and leaf area (255.4 $\mathrm{cm}^{2}$ ) in mango stones treated with $\mathrm{GA}_{3}$ at 200 ppm. Increase in different growth parameters by mechanical scarification is might be due to early germination and favorable growing conditions under scarification treatment (Sharma 2016). Centre of forest research and human resource development, Chhindwara (Annual Report, 2006) also reported that the seed of chironji treated mechanically by hammer gave better seedling growth.

\section{Biomass characters}

The statistical analysed data presented in the (Table 1) revealed that the biomass of chironji seedlings was significantly affected by different chemicals at the end of the experiment (180 DAS). The results revealed that among different chemicals, maximum fresh weight of shoot and root (14.33 $\mathrm{g}$ and 8.22 g respectively), dry weight of shoot and root (8.10 $\mathrm{g}$ and $4.25 \mathrm{~g}$ respectively) and total biomass $(12.83 \mathrm{~g})$ was noticed in seeds subjected to $\mathrm{T}_{3}\left(\mathrm{GA}_{3}\right.$ at $\left.200 \mathrm{ppm}\right)$ treatment at the end of the experiment (180 DAS). 
Table.1 Effect of different chemicals on vegetative growth and biomass of chironji seedlings

\begin{tabular}{|c|c|c|c|c|c|c|c|c|c|c|c|c|c|c|}
\hline \multirow{3}{*}{ Treatment } & \multicolumn{3}{|c|}{$\begin{array}{l}\text { Seedling height } \\
\text { (cm) }\end{array}$} & \multicolumn{3}{|c|}{$\begin{array}{c}\text { Stem diameter } \\
(\mathrm{cm})\end{array}$} & \multicolumn{3}{|c|}{$\begin{array}{c}\text { Number of leaves/ } \\
\text { plant }\end{array}$} & \multirow{3}{*}{$\begin{array}{l}\text { Leaf } \\
\text { area } \\
\left(\mathrm{cm}^{2}\right)\end{array}$} & \multicolumn{4}{|c|}{ Biomass (g) } \\
\hline & \multirow{2}{*}{$\begin{array}{c}60 \\
\text { DAS }\end{array}$} & \multirow{2}{*}{$\begin{array}{c}120 \\
\text { DAS }\end{array}$} & \multirow[b]{2}{*}{$\begin{array}{c}180 \\
\text { DAS }\end{array}$} & \multirow[b]{2}{*}{$\begin{array}{c}60 \\
\text { DAS }\end{array}$} & \multirow[b]{2}{*}{$\begin{array}{c}120 \\
\text { DAS }\end{array}$} & \multirow{2}{*}{$\begin{array}{r}180 \\
\text { DAS }\end{array}$} & \multirow[b]{2}{*}{$\begin{array}{c}60 \\
\text { DAS }\end{array}$} & \multirow[b]{2}{*}{$\begin{array}{l}120 \\
\text { DAS }\end{array}$} & \multirow{2}{*}{$\begin{array}{c}180 \\
\text { DAS }\end{array}$} & & \multicolumn{2}{|c|}{ Fresh weight } & \multicolumn{2}{|c|}{ Dry weight } \\
\hline & & & & & & & & & & & $\begin{array}{c}\text { shoot } \\
\text { (g) }\end{array}$ & $\begin{array}{l}\text { root } \\
(\mathrm{g})\end{array}$ & $\begin{array}{c}\text { shoot } \\
\text { (g) }\end{array}$ & $\begin{array}{l}\text { root } \\
(\mathrm{g})\end{array}$ \\
\hline $\mathrm{T}_{1}-\mathrm{H}_{2} \mathrm{SO}_{4} @ 5 \%$ & 6.10 & 13.32 & 30.31 & 0.19 & 0.30 & 0.41 & 4.62 & 9.29 & 13.16 & 44.23 & 11.69 & 7.41 & 7.72 & 3.63 \\
\hline$T_{2}$ - Mechanical scarification & 6.20 & 14.32 & 35.26 & 0.19 & 0.33 & 0.43 & 4.67 & 9.77 & 13.61 & 48.37 & 13.64 & 7.90 & 8.00 & 4.08 \\
\hline$T_{3}-G_{3} @ 200$ ppm & 6.35 & 15.21 & 36.78 & 0.21 & 0.35 & 0.45 & 4.90 & 10.22 & 14.63 & 48.47 & 14.33 & 8.22 & 8.10 & 4.25 \\
\hline$T_{4}-G_{3} @ 300$ ppm & 4.10 & 8.14 & 21.93 & 0.16 & 0.28 & 0.36 & 3.67 & 6.99 & 11.25 & 40.03 & 10.40 & 6.54 & 6.44 & 3.33 \\
\hline $\mathrm{T}_{5}-\mathrm{KNO}_{3} @ 1 \%$ & 4.07 & 8.32 & 21.33 & 0.17 & 0.27 & 0.34 & 2.96 & 6.07 & 10.51 & 38.50 & 10.35 & 5.84 & 5.78 & 3.13 \\
\hline $\mathrm{T}_{6}-\mathrm{KNO}_{3} @ 2 \%$ & 4.30 & 8.14 & 22.43 & 0.17 & 0.29 & 0.39 & 3.15 & 6.21 & 10.64 & 42.28 & 10.56 & 6.72 & 6.68 & 3.23 \\
\hline $\mathrm{T}_{7}$ - Thiourea@1\% & 4.00 & 7.79 & 21.32 & 0.15 & 0.25 & 0.33 & 2.73 & 5.28 & 10.02 & 31.30 & 10.28 & 4.69 & 5.36 & 2.54 \\
\hline $\mathrm{T}_{8}$ - Biomix @ 50gm/kg seed & 4.00 & 7.79 & 20.15 & 0.15 & 0.24 & 0.31 & 2.70 & 5.21 & 10.00 & 27.68 & 10.29 & 4.62 & 5.34 & 2.50 \\
\hline $\mathbf{T}_{9}$ - Cow urine @ 5\% & 4.25 & 8.14 & 22.39 & 0.17 & 0.28 & 0.36 & 3.12 & 6.17 & 10.64 & 38.38 & 10.34 & 6.63 & 6.40 & 3.36 \\
\hline $\mathbf{T}_{10}-$ Cow dung & 4.05 & 8.30 & 21.24 & 0.16 & 0.27 & 0.34 & 2.95 & 6.04 & 10.38 & 35.33 & 10.30 & 5.50 & 5.70 & 3.13 \\
\hline $\mathbf{T}_{11}-$ Control & 3.30 & 6.69 & 14.50 & 0.11 & 0.17 & 0.24 & 2.21 & 4.99 & 8.70 & 18.12 & 10.16 & 4.35 & 3.84 & 2.53 \\
\hline S.Em \pm & 0.14 & 0.40 & 0.63 & 0.01 & 0.01 & 0.01 & 0.10 & 0.30 & 0.36 & 0.36 & 0.24 & 0.28 & 0.18 & 0.08 \\
\hline C.D. at 5\% & 0.40 & 1.16 & 1.83 & 0.02 & 0.02 & 0.03 & 0.30 & 0.88 & 1.07 & 1.07 & 0.70 & 0.82 & 0.53 & 0.24 \\
\hline $\mathrm{CV} \%$ & 5.10 & 7.11 & 4.45 & 5.68 & 3.85 & 4.10 & 5.21 & 7.47 & 5.63 & 1.68 & 3.69 & 7.83 & 4.96 & 4.37 \\
\hline
\end{tabular}


$\mathrm{T}_{2}$ (mechanical scarification) treatment was found to be at par with $\mathrm{T}_{3}$ treatment recording fresh weight of shoot and root (13.64 and $7.90 \mathrm{~g}$ respectively) and dry weight of shoot and root (8.00 and $4.08 \mathrm{~g}$ respectively). The lowest fresh weight of shoot and root (10.16 and $4.35 \mathrm{~g}$ respectively), dry weight of shoot and root (3.84 and $2.53 \mathrm{~g}$ respectively) and total biomass ( $6.35 \mathrm{~g}$ ) was found in control. A possible reason for this might be due to overall growth of the seedling and increased rate of photosynthesis that lead to the overall assimilation and redistribution of photosynthates within the seedling and hence, resulted in higher fresh and dry weight and total biomass. Thus, increased growth is a consequence of increased dry matter accumulation. These results were dully supported by Sharma (2016) in chironji. He revealed that the considerable improvement in fresh and dry weight of shoots (13.00 $\mathrm{g}$ and $8.18 \mathrm{~g}$, respectively), fresh and dry weight of roots (7.93 $\mathrm{g}$ and $4.13 \mathrm{~g}$, respectively) was recorded under $\mathrm{GA}_{3}$ at $200 \mathrm{ppm}$. Similarly, Pampanna and Sulikeri (1999) in sapota observed the highest fresh and dry weight of seedling (1096.37 $\mathrm{mg}$ and $349.00 \mathrm{mg}$ respectively) by treating seed with $\mathrm{GA}_{3}$ at $400 \mathrm{ppm}$ concentration. Results of present investigation showed favorable response of mechanical scarification on fresh and dry weight of shoot and root. It may be due to higher vegetative growth favored by early germination after scarification. The results are in close conformity with the findings of Sharma (2016) in chironji.

Based on the results of the present investigation entitled "Effect of different chemicals on seedling growth and biomass of chironji (Buchanania lanzan Spreng.)", it can be concluded that the seeds soaked in water for $24 \mathrm{hrs}$ followed by dipping in $\mathrm{GA}_{3}$ at 200 ppm for 24 hours gave the optimum vegetative growth and biomass of chironji seedlings. Therefore, pre sowing treatment with gibberellic acid can be used for production of vigorous seedlings with higher biomass of chironji seedling.

\section{References}

Annual report 2006. Centre of forest research and human resource development, Chhindwara, M.P (India).

Manekar, R.S., Sable, P. B., and Rane, M. M. 2011. Influence of different plant growth regulators on seed germination and subsequent seedling growth of aonla (Emblica officinalis Gaertn.). Green Farming, 2(4): 477-478.

Muralidhara, B.M., Reddy, Y. T. N., Akshitha, H. J. and Srilatha, V. 2015. Effect of presowing treatments on germination, growth and vigor of polyembryonic mango seedlings. Environ. \& Eco. 33(3): 1014 - 1018.

Pampanna, Y., and Sulikeri, G. S. 1999. Growth of sapota (Manilkara achras Mill. Foseberg) seedlings as influenced by presowing seed treatment with growth regulators. Seed Res., 27(1): 49-53.

Panse, V.G., and Sukhatme, P. V. 1967. Statistical Methods for Agricultural Workers, Indian Council of Agricultural Research, New Delhi, India.

Rajamanickam, C., Anbu, S. and Balakrishnan, K. 2002. Effect of chemicals and growth regulators on seed germination in aonla (Emblica officinalis G.). South Indian Hort., 50(1-3): 211-214.

Sen, S. K., Hore, I. K. and Bandhopadhyay, A. 1990. Pre-sowing seed treatment and its role in germination, seedling growth and longevity of papaya. Orissa J. Agril. Res., 2(3-4): 160-164.

Sen, S.K., and Ghunti, P. 1976. Effect of presowing seed treatment on the germination and seedling growth in papaya. Orissa J. Hort., 4: 38-43.

Sharma, D.K., 2016. Effect of plant growth regulators and scarification on germination and seedling growth of Chironji (Buchanania lanzan Spreng.). Advances in life sciences, 5 (8): 3237-3241.

\section{How to cite this article:}

Joshi, C.J., D.K. Sharma, Mutteppa Gotur and Rajni Rajan. 2017. Effect of Different Chemicals on Seedling Growth and Biomass of Chironji (Buchanania lanzan Spreng.). Int.J.Curr.Microbiol.App.Sci. 6(9): 1819-1823. doi: https://doi.org/10.20546/ijcmas.2017.609.224 